\title{
The effects of dietary eggshell with membrane and olive leaf extract supplementation on performance, carcass characteristics and some biochemical parameters of quails exposed to heat stress
}

\author{
Zeki ERIŞ̧íR $^{1, a \bowtie}$, Mehtap ÖZÇELİK ${ }^{2, b}$, Mehmet Ali AZMAN ${ }^{3, c}$, Seda İFLAZOĞLU MUTLU ${ }^{4, d}$, \\ Ülkü Gülcihan ŞiMŞEK ${ }^{1, \mathrm{e}}$, Yasin BAYKALIR ${ }^{1, \mathrm{f}}$, Selcen ARSLAN ${ }^{5, \mathrm{~g}}$, Mehmet EROĞLU ${ }^{6, \mathrm{~h}}$, \\ Gonca OZAN KOCAMÜFTÜOĞLU ${ }^{7, i}$, Mehmet ÇiFTÇi ${ }^{4, j}$
}

\begin{abstract}
${ }^{1}$ Firat University, Faculty of Veterinary Medicine, Department of Animal Science, Elazığ ${ }^{2}$ Frrat University, Vocational School of

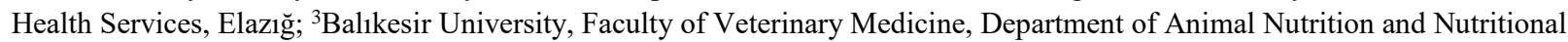
Diseases, Balıkesir; ${ }^{4}$ Frrat University, Faculty of Veterinary Medicine, Department of Animal Nutrition and Nutritional Diseases, Elazı $\breve{g} ;{ }^{5}$ Republic of Turkey Ministry of Agriculture and Forestry Elazı $\breve{g}$ Directorate of Provincial Agriculture and Forestry, Elazı $\breve{g}$; ${ }^{6}$ Agriculture and Rural Development Support Institution, Elazı $\breve{g} ;{ }^{7}$ Mehmet Akif Ersoy University, Faculty of Veterinary Medicine, Department of Biochemistry, Burdur, Turkey.

${ }^{\mathrm{a} O R C I D:}$ 0000-0003-0420-023X; b ORCID: 0000-0003-2362-4935; ' $O R C I D: 0000-0001-9281-9520$;

dORCID: 0000-0002-6835-2171; ' $\mathrm{ORCID:0000-0003-2871-3005;} \mathrm{fORCID:} \mathrm{0000-0002-9248-6065;}$
\end{abstract}

gORCID: 0000-0001-9910-6187; ' $\mathrm{h}$ ORCID: 0000-0001-9471-6410; 'ORCID: 0000-0001-6874-3669; iORCID: 0000-0002-3009-8710

Corresponding author: zerisir@hotmail.com

Received date: 19.09.2019- Accepted date: 02.01.2020

\begin{abstract}
This study was conducted to investigate the effects of eggshells with membrane (ESM), the eggshells with membrane that had absorbed olive leaf extract (ESM+OLE) and olive leaf extract (OLE) additives on the performance, immunity, and oxidantantioxidant metabolism of Japanese quails exposed to heat stress. In the experiment, a total of 128 fifteen-day-old quails were divided into 4 groups with 4 replicates. The control group was fed with a maize-soybean based basal diet; the ESM group was fed with a basal diet supplemented with $2 \%$ ESM; the ESM+OLE group was fed with a basal diet consisting of 2\% ESM and 200 ppm olive leaf extract and the OLE group was fed with a basal diet supplemented with $200 \mathrm{ppm}$ olive leaf extract. At the end of the study, carcass characteristics and blood parameters were determined. The highest daily body weight gain and the lowest feed conversion ratio were observed in the OLE group $(\mathrm{P}<0.05)$. OLE was added into feed, MDA levels in the liver and heart decreased significantly $(\mathrm{P}<0.001)$, whereas, GSH-Px and SOD activities in both tissues alongside the GSH levels in the heart increased significantly (P<0.001). The ESM was found to significantly reduce liver MDA levels $(\mathrm{P}<0.001)$, and increase GSH-Px activity in both tissues, along with SOD activity and GSH levels in the heart $(\mathrm{P}<0.001)$. Consequently, the addition of ESM and OLE to the diets positively affected daily body weight gain, serum triglyceride, liver, and heart tissue MDA levels in the quails exposed to heat stress.
\end{abstract}

Keywords: Biochemical parameters, eggshell with membrane, olive leaf extract, performance, quail.

\section{Sıcaklık stresi altındaki bıldırcınlarda yeme zarlı yumurta kabuğu ve zeytin yaprağı özütü ilavesinin performans, karkas özellikleri ve bazı biyokimyasal parametreler üzerine etkisi}

Özet: Bu çalışma, sıcaklık stresine maruz bırakılmış Japon bıldırcınlarında, yeme zarlı yumurta kabuğu (ESM), zarlı yumurta kabuğuna emdirilmiş zeytin yaprağı özütü (ESM+OLE) ve zeytin yaprağı özütü (OLE) ilavesinin performans, immünite ve oksidanantioksidan metabolizma üzerine olan etkilerini incelemek amacıyla yapılmıştır. Denemede, 15 günlük yaşta toplam 128 adet bıldırcın 4 tekerrürlü 4 gruba ayrılmıştır. Mısır-soya esasına dayalı bazal diyeti tüketen kontrol grubu, bazal diyete \%2 zarlı yumurta kabuğu ilavesi ESM grubunu, bazal diyete \%2 ESM + 200 ppm dozunda zeytin yaprağ özütü ilavesi ESM+OLE grubunu ve bazal diyete 200 ppm dozunda OLE ilave edilen OLE grubunu oluşturmuştur. Araştırma sonunda karkas özellikleri ve kan parametreleri belirlenmiştir. En iyi canlı ağırlık artışı ve yemden yararlanma OLE grubunda gözlenmiştir $(\mathrm{P}<0,05)$. Yeme ilave edilen OLE'nin karaciğer ve kalp MDA düzeylerini önemli olarak azalttığı $(\mathrm{P}<0,001)$, her iki doku GSH-Px ve SOD aktivitelerini, kalp GSH düzeylerini önemli olarak artırdığı $(\mathrm{P}<0,001)$ tespit edilmiştir. ESM'nin ise karaciğer MDA düzeylerini önemli olarak azalttığı $(\mathrm{P}<0,001)$, her iki doku GSH-Px aktivitesini, kalp SOD aktivitesi ve GSH düzeylerini ise önemli olarak artırdığı $(\mathrm{P}<0,001)$ bulunmuştur. Sonuç olarak, sıcaklık stresi altındaki bıldırcınlarda yeme katılan ESM ve OLE’nin, günlük canlı ağırlık artışını, serum trigliserit, karaciğer ve kalp dokusu MDA düzeylerini olumlu yönde etkilediği görülmüştür.

Anahtar sözcükler: Bıldırcın, biyokimyasal parametreler, performans, zarlı yumurta kabuğu, zeytin yaprağı özütü. 

Selcen Arslan - Mehmet Eroğlu - Gonca Ozan Kocamüftüoğlu - Mehmet Çiftçi

\section{Introduction}

Heat stress is one of the important environmental factor decreasing productivity in poultry farming. Despite the continuous change in ambient temperature, all the homeothermic animals have to keep their body temperature constant in order to survive (29). Various chemicals, drugs, antibiotics, and plant extracts used to prevent the negative effects of heat stress on poultry has increased in recent years and are added into the diets and drinking water of the animals in addition to vitamin and mineral matters (14). Eggshell is a by-product of household waste, restaurants, hatcheries, and egg factories (26). Composition of eggshells are comprised of $98.2 \%$ calcium carbonate, $0.9 \%$ magnesium, and $0.9 \%$ phosphate (17). Eggshell membranes, likewise, are composed of moisture (1.5\%), protein $(69.2 \%)$, fat $(2.7 \%)$ and ash (27.2\%) (21). Makkar et al. (22) have reported that the addition of eggshell with membrane into broiler diet has a positive effect on performance and immunity without any negative effect on other physiological parameters.

Olive trees are rich in phenolic components and have significant biological characteristics, the most significant of which is oleuropein (OLE) (28). OLE is found naturally in olive leaves and fruits and is the main reason behind why the olive fruit carries a bitter taste. This bitterness prevents olives from being consumed immediately after they are harvested. Additionally, olive trees can live for thousands of years because of this special phenolic compound $(5,16,23)$. Bahsi et al. (6) concluded that when the olive oil extract (oleuropein) is added to the diet of the quails reared in different stocking densities, it enhances both performance and the quality of the brisket lipid by decreasing saturated fatty acid rates and increasing polyunsaturated fatty acid levels.

In the light of this information, this study was conducted to determine the effects of eggshell with membrane, olive leaf extract absorbed by the eggshell with membrane, and olive leaf extract additives on growth performance, immunity, and antioxidant metabolism in the quails exposed to heat stress.

\section{Material and Methods}

Experimental design and diets: A total number of 128 Japanese quails (Coturnix coturnix Japonica) were used in this study. Approval of Frrat University Animal Research Ethics Committee (Protocol Number: 2016/69). The study was carried out at the Poultry Unit, Faculty of Veterinary, Frrat University.

This study included four groups. Control group consumed basal diet based on maize-soybean. Eggshell membrane (ESM) group was fed with a basal diet containing addition of $2 \%$ ESM. ESM + olive leaf extract
(OLE) group was fed with a basal diet containing 2\% ESM +200 ppm OLE. OLE group was fed with a basal diet supplemented with 200 ppm OLE. Each group consisted of 15-day-old 32 quails including 16 males and 16 females. Each group was formed with 4 replicates and including 8 animals ( 4 males and 4 females). Water was given ad libitum to each of the groups, alongside 24-hour lighting. The quails were kept in heat-controlled cells in broiler raising cages. The feed used was a quail grower feed (24\% HP, $2900 \mathrm{kcal} / \mathrm{kg} \mathrm{ME})$ that was prepared in accordance with minimum NRC standards (27) and provided by regional producers. Table 1 shows the ingredients and nutrient composition of experimental diets. Metabolizable energy levels (8) and chemical composition of diets (dry matter, crude protein, crude fibre, ether extract, crude ash, calcium, available phosphorus, sodium, lysine and threonine) were calculated (27). Olive leaf extract was supplied from a commercial company (DÜAG, Natural Products Agriculture Machinery Plant and Microbiological Products Research Development Industry and Trade Limited Company, Izmir, Turkey). The concentration of phenolic substances in the olive leaf extract was determined by HPLC and is shown in Table 2. After the animals reached 8 days of age, they were left to adapt for an additional 7 days and then, on the $15^{\text {th }}$ day, they were weighed and assigned to the study groups. The quails were exposed to heat stress for 8 hours between 09:00 and 17:00 every morning at poultry unit with temperature of 37 $38^{\circ} \mathrm{C}$. The poultry unit were then kept under thermoneutral conditions of $18-22{ }^{\circ} \mathrm{C}$ between $17.00-09.00$. The body weights of the quails in the groups were measured at the beginning of the experiment and weekly $(22,29,36$, and 43 day-old). While the quails were fed daily, their feed was weighed weekly, and daily feed intake was calculated. The daily body weight gain was determined during the production period and the feed conversion ratio was calculated by dividing daily feed intake to daily body weight gain. At the end of trial (43 days-old), 6 quails (3 males and 3 females) in each experimental group were decapitated to determine their carcass characteristics and blood parameters. Blood samples were taken into tubes during the decapitation. The glucose, triglyceride, calcium, uric acid, creatine and IgM levels of the serums were analyzed (Olympus AU-600). MDA and GSH levels, SOD and GSH-Px activities were determined in liver and heart tissues. While MDA and GSH levels were determined based on the method of Placer et al. (31), GSH level was found based on method of Chavan et al. (9). While the method of Matkovics et al. (25) was used for measurement of GSH-Px activity, Sun et al. (37) method was used to measure SOD activity. The protein content in tissues was measured using Lowry et al. method (19). 
Table 1. Ingredients and nutrient composition of experimental diets $(\%)^{1}$

\begin{tabular}{|c|c|c|}
\hline Item & $\mathbf{C}$ & ESM \\
\hline Maize & 40.80 & 40.80 \\
\hline Soybean meal (48 \%CP) & 24.30 & 24.30 \\
\hline Corn gluten (43\%CP) & 13.50 & 13.50 \\
\hline Wheat & 14.25 & 13.75 \\
\hline Wheat bran & 3.40 & 3.40 \\
\hline Dicalcium phosphate & 0.61 & 0.61 \\
\hline Ground limestone & 1.50 & - \\
\hline Salt & 0.40 & 0.40 \\
\hline DL-Methionine & 0.34 & 0.34 \\
\hline L-Lysine hydrochloride & 0.30 & 0.30 \\
\hline L-Threonine & 0.20 & 0.20 \\
\hline Vitamin-Mineral mix $* *$ & 0.40 & 0.40 \\
\hline ESM & - & 2.00 \\
\hline \multicolumn{3}{|c|}{ Nutritional composition $(\%)^{3}$} \\
\hline Dry matter & 89.80 & 87.90 \\
\hline Crude protein & 24.00 & 24.00 \\
\hline Crude fibre & 3.41 & 3.45 \\
\hline Ether extract & 6.25 & 6.15 \\
\hline Crude ash & 6.35 & 6.50 \\
\hline Calcium & 0.90 & 0.96 \\
\hline Available phosphorus & 0.28 & 0.28 \\
\hline Sodium & 0.20 & 0.20 \\
\hline Lysine & 1.34 & 1.33 \\
\hline Threonine & 1.04 & 1.03 \\
\hline $\mathrm{ME}, \mathrm{kcal} / \mathrm{kg}^{4}$ & 2900 & 2900 \\
\hline
\end{tabular}

Table 2. Phenolic substances of olive leaf extract $(\mathrm{mg} / \mathrm{g})$

\begin{tabular}{lc}
\hline Phenolics & $\mathbf{~ g / g}$ \\
\hline Oleuropein & 103 \\
Rutin & 32 \\
Catechin & 1.5 \\
Hydroxytyrosol & 12 \\
Caffeic acid & 3.6 \\
Vanillic acid & 4.1 \\
Vanillin & 3.2 \\
\hline
\end{tabular}

Hot carcass weight and weights of some organs (heart, liver, and spleen) were determined. Yield was calculated in percentage by dividing hot carcass, liver, spleen, and heart weights to slaughter weight (4).

Statistical analysis: After test of normality, one-way analysis of variance was used to determine the effects of experimental groups on examined parameters. The Tukey
HSD test was then utilized for further analysis. SPSS packaged software was used to assess the data. The $\mathrm{P}$ value of $<0.05$ was accepted as statistically significant (36).

\section{Results}

Table 3 shows body weight, daily body weight gain, feed intake and feed conversion ratio values of groups. There were no differences among the groups in terms of body weight and feed intake. Significant difference in daily body weight gain was revealed among the groups from the day 15 to the day $43(\mathrm{P}<0.05)$. The highest daily body weight gain was determined in the OLE group. Feed conversion ratio, however, varied significantly among groups $(\mathrm{P}<0.05)$, namely in favor of OLE group. No differences among the groups in carcass characteristics was found (Table 4). 
Table 3. The effect of dietary eggshell with membrane and olive leaf extract supplement on performance of Japanese quail under heat stress

\begin{tabular}{|c|c|c|c|c|c|}
\hline Traits & $\mathbf{C}$ & ESM & ESM+OLE & OLE & $\mathbf{P}$ \\
\hline \multicolumn{6}{|l|}{ Body weight, g } \\
\hline Day 15 & $44.94 \pm 1.83$ & $44.94 \pm 1.81$ & $44.94 \pm 1.68$ & $44.88 \pm 2.14$ & 1.00 \\
\hline Day 22 & $83.74 \pm 2.72$ & $81.87 \pm 2.69$ & $81.55 \pm 2.68$ & $81.97 \pm 2.27$ & 0.93 \\
\hline Day 29 & $115.16 \pm 4.24$ & $118.71 \pm 3.75$ & $115.33 \pm 4.17$ & $118.27 \pm 4.24$ & 0.89 \\
\hline Day 36 & $143.13 \pm 5.35$ & $151.16 \pm 3.90$ & $145.07 \pm 4.51$ & $147.53 \pm 4.75$ & 0.64 \\
\hline Day 43 & $168.62 \pm 5.78$ & $173.55 \pm 4.57$ & $167.73 \pm 5.30$ & $177.38 \pm 5.01$ & 0.52 \\
\hline \multicolumn{6}{|c|}{ Body weight gain, g / bird / day } \\
\hline Days $15-22$ & $5.51 \pm 0.36$ & $5.31 \pm 0.12$ & $5.24 \pm 0.29$ & $5.29 \pm 0.14$ & 0.88 \\
\hline Days $22-29$ & $4.51 \pm 0.46$ & $5.18 \pm 0.20$ & $4.84 \pm 0.73$ & $5.22 \pm 0.51$ & 0.74 \\
\hline Days $29-36$ & $3.94 \pm 0.48$ & $4.63 \pm 0.25$ & $4.25 \pm 0.14$ & $4.22 \pm 0.37$ & 0.56 \\
\hline Days $36-43$ & $3.71 \pm 0.17$ & $3.18 \pm 0.44$ & $3.29 \pm 0.53$ & $4.20 \pm 0.27$ & 0.27 \\
\hline Days 15 - 43 & $4.42 \pm 0.09^{\mathrm{b}}$ & $4.58 \pm 0.05^{\mathrm{ab}}$ & $4.41 \pm 0.08^{\mathrm{b}}$ & $4.73 \pm 0.08^{\mathrm{a}}$ & 0.03 \\
\hline \multicolumn{6}{|c|}{ Feed intake, g / bird / day } \\
\hline Days $15-22$ & $22.54 \pm 0.47$ & $23.70 \pm 3.08$ & $20.70 \pm 1.23$ & $19.43 \pm 1.45$ & 0.39 \\
\hline Days $22-29$ & $17.07 \pm 0.69$ & $15.64 \pm 0.42$ & $15.81 \pm 0.99$ & $16.38 \pm 0.96$ & 0.59 \\
\hline Days $29-36$ & $20.13 \pm 0.71$ & $21.08 \pm 0.68$ & $19.58 \pm 0.42$ & $20.22 \pm 0.58$ & 0.41 \\
\hline Days $36-43$ & $22.65 \pm 0.96$ & $22.57 \pm 1.17$ & $22.39 \pm 1.53$ & $23.35 \pm 1.31$ & 0.95 \\
\hline Days 15 - 43 & $20.60 \pm 0.39$ & $20.75 \pm 1.21$ & $19.62 \pm 0.69$ & $19.84 \pm 0.82$ & 0.73 \\
\hline \multicolumn{6}{|c|}{ Feed conversion ratio, g feed / g gain } \\
\hline Days 15 - 22 & $4.15 \pm 0.33$ & $4.47 \pm 0.60$ & $4.01 \pm 0.43$ & $3.69 \pm 0.30$ & 0.65 \\
\hline Days 22 - 29 & $3.94 \pm 0.51$ & $3.04 \pm 0.17$ & $3.52 \pm 0.62$ & $3.21 \pm 0.28$ & 0.50 \\
\hline Days 29 - 36 & $5.29 \pm 0.50$ & $4.58 \pm 0.19$ & $4.62 \pm 0.21$ & $4.90 \pm 0.45$ & 0.51 \\
\hline Days 36 - 43 & $6.11 \pm 0.11^{\mathrm{ab}}$ & $7.31 \pm 0.52^{\mathrm{a}}$ & $7.11 \pm 0.65^{\mathrm{a}}$ & $5.58 \pm 0.19^{\mathrm{b}}$ & 0.05 \\
\hline Days $15-43$ & $4.87 \pm 0.21^{\mathrm{a}}$ & $4.85 \pm 0.09^{\mathrm{a}}$ & $4.82 \pm 0.11^{\mathrm{a}}$ & $4.34 \pm 0.13^{\mathrm{b}}$ & 0.05 \\
\hline
\end{tabular}

C: Control, ESM: Eggshell with membrane, ESM+OLE: Eggshell with membrane + Olive leaf extract, OLE: Olive leaf extract Data were given as mean \pm SEM, a,b: Mean values with different superscripts within a row differ significantly $(\mathrm{P}<0.05)$.

Table 4. The effect of dietary eggshell with membrane and olive leaf extract supplement on carcass characteristic of Japanese quail under heat stress

\begin{tabular}{lccccc}
\hline Traits & C & ESM & ESM+OLE & OLE & P \\
\hline Slaughter weight, g & $164.17 \pm 17.55$ & $168.67 \pm 5.87$ & $163.83 \pm 8.51$ & $172.50 \pm 9.37$ & 0.94 \\
Carcass weight, g & $110.28 \pm 12.66$ & $115.28 \pm 3.80$ & $110.07 \pm 6.66$ & $118.20 \pm 5.89$ & 0.86 \\
Carcass yield, \% & $66.84 \pm 2.09$ & $68.42 \pm 1.09$ & $67.09 \pm 1.44$ & $68.63 \pm 1.07$ & 0.77 \\
Liver weight, g & $4.48 \pm 0.53$ & $3.88 \pm 0.30$ & $4.29 \pm 0.42$ & $3.89 \pm 0.33$ & 0.66 \\
Liver, \% & $2.80 \pm 0.27$ & $2.29 \pm 0.13$ & $2.61 \pm 0.18$ & $2.26 \pm 0.15$ & 0.17 \\
Heart weight, g & $1.37 \pm 0.17$ & $1.51 \pm 0.07$ & $1.47 \pm 0.11$ & $2.36 \pm 0.94$ & 0.45 \\
Heart, \% & $0.84 \pm 0.06$ & $0.89 \pm 0.03$ & $0.90 \pm 0.05$ & $1.27 \pm 0.41$ & 0.47 \\
Spleen weight, g & $0.24 \pm 0.07$ & $0.16 \pm 0.02$ & $0.17 \pm 0.04$ & $0.16 \pm 0.02$ & 0.45 \\
Spleen, \% & $0.16 \pm 0.05$ & $0.09 \pm 0.01$ & $0.11 \pm 0.02$ & $0.09 \pm 0.01$ & 0.24 \\
\hline
\end{tabular}

C: Control, ESM: Eggshell with membrane, ESM+OLE: Eggshell with membrane + Olive leaf extract, OLE: Olive leaf extract. Data were given as mean \pm SEM 
Table 5. The effect of dietary eggshell with membrane and olive leaf extract supplement on some biochemical parameters of Japanese quail under heat stress

\begin{tabular}{lccccc}
\hline Traits, $(\mathbf{m g} / \mathbf{d L})$ & C & ESM & ESM+OLE & OLE & P \\
\hline Glucose & $170.02 \pm 20.64$ & $184.28 \pm 12.73$ & $169 \pm 16.19$ & $181.98 \pm 13.32$ & 0.86 \\
Triglyceride & $141.20 \pm 19.00^{\mathrm{a}}$ & $93.33 \pm 6.57^{\mathrm{b}}$ & $113.73 \pm 5.64^{\mathrm{ab}}$ & $88.58 \pm 7.63^{\mathrm{b}}$ & 0.01 \\
Calcium & $5.96 \pm 1.00$ & $5.46 \pm 0.52$ & $4.78 \pm 0.36$ & $5.84 \pm 0.34$ & 0.41 \\
Uric Acid & $6.65 \pm 0.99$ & $4.86 \pm 0.64$ & $6.58 \pm 0.64$ & $5.67 \pm 0.72$ & 0.34 \\
Creatine & $0.10 \pm 0.04$ & $0.04 \pm 0.01$ & $0.11 \pm 0.02$ & $0.07 \pm 0.02$ & 0.18 \\
Ig M & $0.03 \pm 0.01$ & $0.04 \pm 0.01$ & $0.03 \pm 0.01$ & $0.02 \pm 0.01$ & 0.20 \\
\hline
\end{tabular}

C: Control, ESM: Eggshell with membrane, ESM+OLE: Eggshell with membrane + Olive leaf extract, OLE: Olive leaf extract. Data were given as mean \pm SEM, a,b: Mean values with different superscripts within a row differ significantly $(\mathrm{P}<0.05)$.

Table 6. The effect of dietary eggshell with membrane and olive leaf extract supplement on stress parameters of Japanese quail under heat stress

\begin{tabular}{|c|c|c|c|c|c|}
\hline Traits & $\mathbf{C}$ & ESM & ESM+OLE & OLE & $\mathbf{P}$ \\
\hline \multicolumn{6}{|c|}{ MDA (nmol / g protein) } \\
\hline Liver & $11.46 \pm 0.63^{\mathrm{a}}$ & $7.91 \pm 0.42^{b}$ & $7.73 \pm 0.35^{\mathrm{b}}$ & $8.53 \pm 0.62^{b}$ & $<0.001$ \\
\hline Heart & $15.69 \pm 0.99^{\mathrm{a}}$ & $13.97 \pm 0.78^{\mathrm{ab}}$ & $12.77 \pm 0.33^{\mathrm{b}}$ & $12.98 \pm 0.70^{\mathrm{b}}$ & 0.041 \\
\hline \multicolumn{6}{|c|}{ GSH (nmol / g protein) } \\
\hline Liver & $0.83 \pm 0.11$ & $0.92 \pm 0.24$ & $1.04 \pm 0.07$ & $1.19 \pm 0.09$ & 0.332 \\
\hline Heart & $3.49 \pm 0.36^{\mathrm{c}}$ & $4.78 \pm 0.21^{\mathrm{b}}$ & $5.26 \pm 0.32^{\mathrm{ab}}$ & $5.95 \pm 0.30^{\mathrm{a}}$ & $<0.001$ \\
\hline \multicolumn{6}{|c|}{ GSH-Px (U / mg protein) } \\
\hline Liver & $4.18 \pm 0.38^{\mathrm{b}}$ & $5.21 \pm 0.18^{\mathrm{a}}$ & $5.16 \pm 0.19^{\mathrm{a}}$ & $5.19 \pm 0.23^{\mathrm{a}}$ & 0.024 \\
\hline Heart & $49.66 \pm 4.12^{\mathrm{b}}$ & $64.74 \pm 2.66^{\mathrm{a}}$ & $50.19 \pm 1.75^{\mathrm{b}}$ & $62.29 \pm 4.27^{\mathrm{a}}$ & 0.006 \\
\hline \multicolumn{6}{|c|}{ SOD (U / g protein) } \\
\hline Liver & $0.98 \pm 0.10^{\mathrm{b}}$ & $1.14 \pm 0.08^{\mathrm{ab}}$ & $1.34 \pm 0.11^{\mathrm{a}}$ & $1.38 \pm 0.08^{\mathrm{a}}$ & 0.026 \\
\hline Heart & $4.70 \pm 0.37^{\mathrm{c}}$ & $6.23 \pm 0.36^{\mathrm{b}}$ & $5.49 \pm 0.23^{\mathrm{bc}}$ & $7.98 \pm 0.43^{\mathrm{a}}$ & $<0.001$ \\
\hline
\end{tabular}

C: Control, ESM: Eggshell with membrane, ESM+OLE: Eggshell with membrane + Olive leaf extract, OLE: Olive leaf extract. Data were given as mean $\pm \mathrm{SEM}$, a,b,c: Mean values with different superscripts within a row differ significantly $(\mathrm{P}<0.05)$.

The addition of ESM and OLE to the diets of the quails exposed to heat stress did not lead to any change in glucose, calcium, uric acid, creatine and IgM levels; however, it did cause a decrease triglyceride levels, significantly $(\mathrm{P}<0.01)$ (Table 5). When the oxidant and antioxidant parameters were examined, it was determined that OLE added to the diet decreased the liver $(\mathrm{P}<0.001)$ and heart $(\mathrm{P}<0.05)$ MDA levels significantly and increased GSH-Px and SOD enzyme activities of both tissues and heart GSH levels significantly $(\mathrm{P}<0.001)$. The ESM was found to significantly decrease liver MDA levels $(\mathrm{P}<0.001)$, and increase GSH-Px activity in both tissues, along with SOD activity and GSH levels in the heart $(\mathrm{P}<0.001)$. In the ESM+OLE group, MDA levels in the liver and heart decreased significantly $(\mathrm{P}<0.001)$, whereas GSH-Px, SOD activities in the liver and GSH levels in the heart increased significantly $(\mathrm{P}<0.001)$ (Table $6)$.

\section{Discussion and Conclusion}

In poultry farming, heat stress is known to have a negative impact on fattening performance $(2,33)$.
Numerous studies have revealed that addition of some supplements to the diets eliminate the negative effects caused by heat stress $(2,33)$. This study also showed that the ESM group had a significant increase in daily body weight gain compared to control group (Table 3). The increase in body weight gain in ESM group was an expected result, when considering the fact that ESM addition to diet promotes bone weighting. Makkar et al. (22) also stated that supplementation of eggshells to the diets increased body weight in broiler chickens. In this study, supplementation of ESM to the diet did not have any effects on the feed intake and feed conversion ratio. No differences were found among the groups in carcass weight and organ weights. Makkar et al. (22) reported similar results to the present study. Daily body weight gain was not positively affected by the addition of ESM+OLE to the diet. Furthermore, no differences were observed in the ESM+OLE group in feed intake, feed conversion ratio, or carcass characteristics at the end of the period.

In this study, supplementation of OLE in diets had a positive effect on daily body weight gain (Table 3 ). Similarly, Bahşi et al. (6) also stated that supplementation 
of 400 ppm OLE to diets positively affected daily body weight gain. El-Damrawy et al. (12) reported olive leave powder added to ration $(0.5,1,2 \%)$ increased body weight and improved feed conversion. Özdemir and Azman (28) also reported the similar results. In contrast, Sarica and Toptas (35) stated that supplementation of $200 \mathrm{mg} / \mathrm{kg}$ OLE in diet did not affect daily body weight gain. However, supplementation of OLE in diet did not change the daily feed intake, but it positively affected feed conversion ratio. Similarly, Bahsi et al. (6) also reported that adding $400 \mathrm{ppm}$ OLE in diets positively influenced feed conversion ratio. In the present study it was observed that the addition of OLE did not change carcass weight and organ weights and Bahsi et al. (6) also expressed similar results.

It is known that heat stress changes the biochemical blood parameters in poultry $(13,20,34,38)$. Increased serum triglyceride (TG) levels indicate the changes in fat metabolism during heat stress in quails and broilers (11, 20, 38). In this study, it was determined that supplementation of ESM and OLE in diets had a significant decreasing effect on triglyceride levels. Eggshell calcium is probably the best natural source of calcium and is about $90 \%$ absorbable (17). Calcium is the largest mineral found in eggshells, and moreover activates the lipase (32). The activation of lipase may cause the significant decrease in serum triglyceride levels when eggshells are added. Olive leaf extract (OLE) and hydroxytyrosol (OLE hydrolysis product) are the main polyphenolic substances of the olive leaves and unprocessed olive drupes of Olea europaea, which exhibit hypolipidemic effects $(1,12,24,35)$. The olive leaf extract markedly reduces serum and liver triglycerides $(1,12,24$, 30). Also total blood cholesterol, LDL, and triglyceride levels significantly decreased in parallel to an increase in OLE content $(1,12,30)$. Similarly, this study revealed a significant decrease in serum triglyceride levels with addition of OLE to the diet of the quails exposed to heat stress. Malliou et al. (24) reported that OLE activated the hormone sensitive lipase in white adipose tissue and liver and up-regulated several hepatic genes involved in TG uptake, transport, metabolism, and clearance for TG homeostasis. Similar to the present study, other studies (1, $6,12)$ also noted that dietary oleuropein and powdered olive leaves did not have any effect on blood glucose level in layer hens, Mandarah chicks, or quails reared in different stocking densities. Likewise, Parsaei et al. (30) reported that there were no significant differences in total Ig and IgM in broiler chickens fed with diets containing olive leaf powder.

In poultry, heat stress is a major factor that causes the increased production of mitochondrial reactive oxygen species (ROS) in tissue. ROSs are highly reactive and can diffuse into vital cellular targets such as DNA, proteins and membrane, ultimately leading to cell death. When ROS reacts with the unsaturated free fatty acids found in membrane lipids, MDA levels elevate, thereby activating lipid peroxidation. MDA levels are known to significantly increase in the livers of broiler chickens, ducks, and quails exposed to high heat $(10,13)$. Numerous surveys have also stated antioxidant characteristics of $\operatorname{OLE}(1,3,7)$. Studies conducted with poultry have shown that the olive leaves extract and powdered olive leaves, added to the diets at the increasing amounts, decrease MDA in white blood cells, muscle, and plasma and increase SOD and total antioxidant capacity in white blood cells and plasma (1, $12,35)$. This study found that ESM+OLE and OLE added to the diets significantly lowered MDA levels in liver and heart. The supplementation of OLE in the diet significantly elevated GSH-Px, SOD activities in the liver and heart and heart tissue GSH level, in the quails under heat stress. Phenolic compounds in the olive leaf extract are a free radical scavenger because they break the free radical chain reaction $(15,18)$. Interestingly, supplementation of eggshells also caused MDA levels in liver and heart tissue to dramaticallyi drop and may be due to the minerals with antioxidant characteristics in eggshell.

In conclusion, it was determined that eggshells and OLE added in the diets positively affect daily body weight gain. OLE had a positive effect on feed conversion ratio in the quails exposed to heat stress. Furthermore, ESM and OLE significantly reduces serum triglyceride alongside MDA level in liver tissue. These materials can be used in order to obtain positive properties in quail production.

\section{Financial Support}

This research received no grant from any funding agency/sector.

\section{Ethical Statement}

This study was approved by the Firat University Animal Research Ethics Committee (Protocol Number: 2016/69).

\section{Conflict of Interest}

The authors declared that there is no conflict of interest.

\section{References}

1. Ahmed MM, El-Saadany AS, Shreif EY, et al (2017): Effect of dietary olive leaves extract (oleuropein) supplementation on productive, physiological and immunological parameters in bandarah chickens 2- during production period. Egypt Poult Sci, 37, 277-292.

2. Al-Sultan S, Abdel-Raheem S, Abd-Allah S, et al (2019): Alleviation of chronic heat stress in broilers by dietary supplementation of novel feed additive combinations. Slov Vet Res, 56, 269-279. 
3. Andreadou I, Iliodromitis EK, Mikros E, et al (2006): The olive constituent oleuropein exhibits anti-ischemic, antioxidative, and hypolipidemic effects in anesthetized rabbits. J Nutr, 136, 2213-2219.

4. Anon (2009): Poultry Carcass-Rules for Carcass Dissecting. Institute of Turkish Standards, TS 5890, Ankara, Turkey. ICS 67.120.10; 67.120.20.

5. Atik Z, Ceylan N (2009): Yumurta kabuk kalitesine mineral maddelerin etkisi. Tavukçuluk Araş Derg, 6, 50-57.

6. Bahsi M, Ciftci M, Simsek UG, et al (2016): Effects of olive leaf extract (oleuropein) on performance, fatty acid levels of breast muscle and some blood parameters in Japanese quail (Coturnix coturnix Japonica) reared in different stocking densities. Ankara Univ Vet Fak Derg, 63, 61-68.

7. Barbaro B, Toietta G, Maggio R, et al (2014): Effects of the olive-derived polyphenol oleuropein on human health. Int J of Mol Sci, 15, 18508-18524.

8. Carpenter KJ, Clegg KM (1956): The metabolizable energy of poultry feedingstuffs in relation to their chemical composition. J Sci Fd Agric, 7, 45-51.

9. Chavan S, Sava L, Saxena V, et al (2005): Reduced Glutathione: Importance of specimen collection. Indian $\mathrm{J}$ Clin Biochem, 20, 150-152.

10. Ciftci M, Simsek UG, Dalkilic B, et al (2016): Effect of dietary orange peel extract on physiological, biochemical, and metabolic responses of Japanese quail reared under low ambient temperature. Turk J Vet Anim Sci, 40, 288297.

11. El-Damrawy SZ, Khalifah MM, Wesam AF (2013): Dietary olive leaf and antioxidant status in chickens performance, some physiological treats and immunological response of Mandarah chicks supplemented olive leaves powder in their diets. Egypt Poult Sci, 33, 279-287.

12. El-Damrawy SZ (2014): Effect of grape seed extract on some physiological changes in broilers under heat stress. Egypt Poult Sci, 34, 333-343.

13. Erisir Z, Simsek UG, Ozcelik M, et al (2018): Effects of dietary grape seed on performance and some metabolic assessments in Japanese quail with different plumage colors exposed to heat stress. R Bras Zootec, 47, e20170172.

14. Gunther E (1950): The Essential Oils. London: Van Nostrand Company, The essential oils. Van Nostrand Company. London.

15. Hayes JE, Allen P, Brunton N, et al (2011): Phenolic composition and in vitro antioxidant capacity of four commercial phytochemical products: olive leaf extract (Olea europaea L.) lutein, sesamol and ellagic acid. Food Chem, 126, 948-955.

16. Japon-Lujan R, Luque-Rodriguez J, Luque de Castro $M$ (2006): Dynamic ultrasoundassisted extraction of oleuropein and related biophenols from olive leaves. J Chromatogr A, 1108, 76-82.

17. King'ori AM (2011): A Review of the uses of poultry egg shells and shell membranes. Int J of Poult Sci, 10, (11), 908912.

18. Lee OH, Lee BY (2010): Antioxidant and antimicrobial activities of individual and combined phenolics in Olea europaea leaf extract. Bioresour Tech, 101, 3751-3754.

19. Lowry OH, Rosenbrough NJ, Farr AL, et al (1951): Protein measurements with the folin phenol reagent. J Biol Chem, 193, 265-275.
20. Lu Z, He XF, Ma BB, et al (2019): Increased fat synthesis and limited apolipoprotein B cause lipid accumulation in the liver of broiler chickens exposed to chronic heat stress. Poult Sci, 98, 3695-3704.

21. MacNeil J (1997): Separation and Utilization of Waste Egg Shell. In: Proceeding of International egg commission annual production and marketing conference. Toronto, Ontario.

22. Makkar S, Rath NC, Packialakshmi B, et al (2015): Nutritional effects of egg shell membrane supplements on chicken performance and immunity. Poult Sci, 94, 11841189.

23. Malik NSA, Bradford JM (2006): Changes in oleuropein levels during differentiation and development of floral buds in "arbequina” olives. Sci Hort, 110, 274-278.

24. Malliou F, Andreadou I, Gonzalez FJ (2018): The olive constituent oleuropein, as a PPAR $\alpha$ agonist, markedly reduces serum triglycerides. J Nutr Biochem, 59, 17-28.

25. Matkovics B, Szabo I, Varga IS (1988): Determination of enzyme activities in lipid peroxidation and glutathione pathways. Laboratoriumi Diagnosztika, 15, 248-249.

26. Nakano T, Ikama Ikawa NI, Ozimek L (2003): Chemical composition of egg shell and shell membranes. Poult Sci, 82, 510-514.

27. NRC (1994): Nutrient Requirements of Poultry. 44-45. In: National Research Council. National Academy Press, Washington, DC, USA.

28. Ozdemir A, Azman MA (2012): Bıldircın karma yemlerine zeytin yaprağı özütü katılmasının verim performansı ve bazı kan parametreleri üzerine etkileri. Doktora Tezi. Fırat Üniversitesi Sağlık Bilimleri Enstitüsü, Elazığ.

29. Ozkan K (1992): Sicak İklim Koşullarında Kanatlıların Beslenmesi. 84-88. Tavukçulukta Verimlilik Sempozyumu. İzmir, Türkiye.

30. Parsaei S, Amini Z, Houshmand M (2014): Effects of olive leaf on blood metabolites and humoral immunity response of broiler chickens. Int J Adv Biol Biom Res, 2, 741-751.

31. Placer ZA, Cushman LL, Johson BC (1966): Estimation of product of lipid peroxidation (malonyl dialdehyde) in biochemical systems. Anal Biochem, 16, 359-364.

32. Rawn JD (1989): Biochemistry. Fatty Acid Metabolism, 424, Neil Patterson Publishers, Carolina Biological Supply Company, Burlington, North Carolina.

33. Sahin K, Sahin N, Kucuk O, et al (2009): Role of dietary zinc in heat-stressed poultry: A review. Poult Sci, 88, 21762183.

34. Sahin N, Hayirli A, Orhan C, et al (2018): Effects of the supplemental chromium form on performance and metabolic profile in laying hens exposed to heat stress. Poult Sci, 97, 1298-1305.

35. Sarica S, Toptas S (2014): Effects of dietary oleuropein supplementation on growth performance, serum lipid concentrations and lipid oxidation of Japanese quails. $\mathrm{J}$ Anim Physiol Anim Nutr (Berl), 98, 1176-1186.

36. SPSS (2002): Inc. SPSS for Windows Release 11.5 Standard Version, Copyright SPSS Inc., 1989-2002. Chicago.

37. Sun Y, Oberley WL, Li Y (1988): A simple method for clinical assay of superoxide dismutase. Clin Chem, 34, 497-500.

38. Tuzcu M, Sahin N, Karatepe M, et al (2008): Epigallocatechin-3-gallate supplementation can improve antioxidant status in stressed quail. Br Poult Sci, 49, 643-648. 